\title{
Impact of Irrigation on Food Security in Bangladesh for the Past Three Decades
}

\author{
M. Wakilur RAHMAN ${ }^{1}$, Lovely PARVIN ${ }^{2}$ \\ ${ }^{1}$ Assistant Professor, Department of Rural Sociology, Bangladesh Agricultural University, Mymensingh, Bangladesh \\ ${ }^{2} \mathrm{PhD}$ Research Fellow, College of Economics and Management, Northwest A\&F University, P. R China \\ E-mail:wakil_bau@yahoo.com,Irahman_bau@yahoo.com \\ Received May 23, 2009; revised June 15, 2009; accepted June 29, 2009
}

\begin{abstract}
Bangladesh has made impressive progress in agriculture sector in the last three decades and has almost become self-sufficient in food grain production. This is a tremendous achievement owing to its small territory and huge population and this was achieved through agricultural mechanization and modernization. Irrigation is one of the leading inputs has direct influence to increase yield, food grains production and plays vital role for ensuring food security in Bangladesh. The present study examined the growth of irrigated area and its impact on food grain production during last three decades. Time series data were used for the study. Different statistical methods such as mean, percentage, linear and exponential growth model were applied for getting meaningful findings. Various technologies have been used for irrigating crops which have contributed to rapid expansion of irrigated area. The conventional irrigation methods (Low Lift Pump, Dhone, Swing Basket, Treadle Pump etc.) were replaced by modern methods (i.e Deep Tube Well and Shallow Tube Well). In addition, surface water irrigation also sharply declined, losing its importance due to lack of new surface irrigation project and the ineffectiveness of earlier project. Groundwater covered 77 percent of total irrigated area and major (62\%) extractions occurred through Shallow Tube Wells (STWs). The rapid expansion of ground water irrigation in respect to STWs irrigation was due to government's withdrawal on restrictions on tube well setting rule, encouraging private sector and the cost effectiveness of Chinese engine which have been affordable to the small and medium farmers. Irrigated area thus, increased by about three times and cropping intensity also increased from 154 to 176 percent. Boro rice, an irrigated crop, consumed 73 percent of the total crop irrigation and contributed to a greater extent in total rice production in Bangladesh. Boro rice alone contributed to 55 percent of total food grain and was also highest (3.44 MT per hectare) compared to aus rice (1.66 MT per hectare) and aman rice (1.99 MT per hectare) per unit production. Consequently, the cultivated area of boro rice increased by 1168 to 4068 thousand hectares. The higher productivity of boro rice has almost helped the nation to meet her food requirements (about 24 Million MT). Boro rice production was highly correlated $(r=.978)$ with irrigated area. Expansion of one hectare of irrigated area added 3.22 MT of boro rice in Bangladesh. Finally, the study suggested for expansion of irrigated areas (ground water and surface water), adoption of modern technologies and formulation of farmers' friendly policy.
\end{abstract}

Keywords: Irrigation, Food Security, Boro Rice and food Grain Production

\section{Introduction}

South Asia is a home of 1.5 billion people most of which live in India and Bangladesh. Bangladesh, the most densely populated country in the world has been suffering from food deficiency for a long time. Food scarcity has remained the major challenge for the government since liberation (Independence, 1971) as it tries to increase food grain production to meet the demands of the nation's growing population. Since the economy of an agrarian society (like Bangladesh) is dominated by agriculture and the livelihoods of the farmers are largely connected with intensive agriculture production. Food grain occupies the lion's share of agricultural GDP and it em- 
ploys about 60 per cent of total labour force [1]. Hence, any internal and external threat (social, political, natural and environmental) to agriculture directly affects food grain production as well as food security of the country.

Food security is defined as access to enough and safe food by all people at all times for maintaining an active and healthy life. Aggregate domestic production and per capita availability of food grains increased in the country over the past decades. But the country still depends on import of food grains (in 2007-08 imported 11.5 percent of total availability) [2]. Therefore, it is timely demand to explore the domestic potentiality and to increase production for attaining the Millennium Development Goal (MDG goal is to reduce the extreme poverty to half by 2015 ensuring food as basic requirements).

Rice is staple food of Bangladeshi people and it constituted about $90 \%$ of the total food grain production [3]. Of the three types of rice $a u s^{1}, a_{m a n}^{2}$ and boro ${ }^{3}$, the Boro rice alone contributed the highest share of total rice production since 1998-99 to date [4]. Therefore, increase of Boro rice production would be a significant possible way to overcome food deficiency in the country. Boro rice is produced in Rabi season (October to March) and it grows totally under irrigated condition. Thus, development of irrigation availability is playing a vital role in this regard.

There are two major sources of irrigation in Bangladesh-surface and ground water. Low Lift pump (LLP), Canal and Traditional (Dhone and Swing basket) are used as a means of technology for surface water irrigation while Deep Tube Wells (DTW) ${ }^{4}$, Shallow Tube Wells (STW) ${ }^{5}$ and Hand Tube wells are used for ground water irrigation. Before70s, irrigation was mainly dependent on surface sources and in the mid-seventies government emphasised on groundwater irrigation with DTW projects. But government soon shifted to STW because of it's suitability to socio-economic status of the farmers (less investment cost, small land holdings, availability in the market, withdrawing restriction on import and STWs spacing) and STWs enclosed 62 per cent of total irrigated area [5]. The total irrigation coverage was increased 1726 to 5898 thousand hectare within the period of 1981-82 to 2006-07 (342 per cent) whereas irrigation potential is estimated at 7,550 thousand hectares [6]. There is still possibility to expand 28 percent of irrigated area according to irrigation potentiality. At present groundwater contributes to 77 percent of total irrigated area in Bangladesh [5].

About 80 percent of groundwater was used for crop

\footnotetext{
${ }^{1,2}$ Mostly rain fed rice, ${ }^{3}$ Irrigated rice, ${ }^{4}$ The discharge capacity of deep tube wells are about 50 lt/sec having greater depths (upto 100-120m) and larger diameter compared to shallow wells. ${ }^{5}$ Shallow Tube wells are small irrigation wells having discharge capacities of 12-15 lt/sec with maximum depths of $40-60 \mathrm{~m}$ and well diameter of $100-150 \mathrm{~mm}$.
}

production in which Boro paddy consumed 73 percent of total irrigation [7]. Hence, Boro rice production is increasing at about $1 \%$ annually and contributes to $55 \%$ of the total rice production [8]. The application of groundwater irrigation increased with the introduction of High Yielding Variety (HYV) seeds to meet the food requirements of a growing population [9]. In contrast the yield potential of the existing HYV rice is more than $4 \mathrm{MT} / \mathrm{ha}$., whereas the average yield realized by the majority of farmers is less than 3.0 MT/ha [2]. Thus, on farm research is important to reduce the production gap. In addition groundwater-based irrigation economy is crucial for increasing domestic production, attaining food security and lifting millions of poor farmers out of poverty. Hence, this paper intends to acquire an integrated understanding of the importance of irrigation, its impacts on food grain production and rural livelihoods and also the role of existing policy and institutional guidance.

\section{Methodology}

The present paper is mainly based on secondary sources of information. Data were collected from Bangladesh Bureau of Statistics (BBS) in the period of 1980-81 to 2006-07. Moreover, Bangladesh Agricultural Development Corporation (BADC), published articles, Economic Review, and Fifth Five Year Plan was also taken as a crucial source of data. After collecting necessary (time series) data, they were analysed using tabular, graphical and econometric techniques. Microsoft Excel and SPSS program was applied for analysing data in a meaningful way. Both linear and exponential equations were used for representing time series data. The equations are as follows-

$$
\mathrm{Y}_{\mathrm{e}}=\mathrm{a}+\mathrm{bt}
$$

and

$$
\mathrm{Y}_{\mathrm{e}}=A \mathrm{e}^{\mathrm{bt}} \text {, }
$$

after taking $\log$ the equation is- $\log \mathrm{Y}_{\mathrm{e}}=\log \mathrm{A}+\mathrm{bt}$

$\mathrm{Y}_{\mathrm{e}}=$ dependent variables

$\mathrm{a}=$ intercept

$\mathrm{b}=$ Co-efficient

$\mathrm{t}=$ time series

\section{Development of Irrigation Technologies and Cropping Intensity}

At the initial stage of irrigation development, the main emphasis was on low lift pump for extracting surface water and later on, Bangladesh Agricultural Development Corporation (BADC) initiated capital-intensive methods for DTW installation in Bangladesh and provided subsidized well components (pumps, drilling equi- 
pment, etc.) for rapid expansion of larger public groundwater irrigation schemes (1960s started from Thakurgoan area, north-western part of Bangladesh). Privatization and expansion of minor irrigation and withdrawal of Government subsidy in irrigation equipment lead to tremendous development of STWs during last two decades [10]. The percentage contribution of different irrigation technologies is shown in Table 1 . Table 1 depicts that the uses of surface irrigation drastically reduced while groundwater irrigation technologies increased significantly.

Modern irrigation mainly consists of DTW and STW which have almost entirely replaced the pioneer Low Lift Pump (LLPs) and at the same time DTWs is gradually loosing its application as it is economically and socially inappropriate [11]. The share of surface water irrigation technologies (LLP) reduced by 41 to 16 percent of total irrigated area during 1981-82 to 2006-07. Again the traditional (i.e dhone, swing basket etc) and canal irrigation coverage sharply declined to about 10 percent (canal 3 percent and traditional 7 percent). On the other hand, ground water irrigation increased significantly particularly due to rapid expansion of STWs technologies. In early 90s the STW and DTW irrigation covered 37 and 24 percent of total irrigated area respectively. Within two decades, STWs occupied 62 percent of total irrigated area while DTW irrigation coverage was only 14 percent. This indicated that small farmers' share on STW ownership has increased significantly over the years in Bangladesh because of less investment cost, easy installation, easy maintenance and can be shared among small groups of farmers, convenient for small landholding owners and withdrawal of import restrictions [12]. It appears from Table 1 that the percentage of irrigated area increased over time. In 1981-82 total irrigated area was 16 percent whereas in 2006-07 it observed 56 of total cultivated area.

Table 1. Percentage of irrigated area by various technologies in Bangladesh.

\begin{tabular}{cccccccccc}
\hline Year & DTW & STW & LPP & Canal & Traditional & Others & $\begin{array}{c}\text { Total irrigated area Total cultivated area } \\
\text { ('000 ) hectare }\end{array}$ & $\begin{array}{c}\text { Percentages of Cropping } \\
\text { irrigated area }\end{array}$ \\
intensity
\end{tabular}

* Indicates both STW and DTW percentages

Table 2. Shows the rice requirements and availability in domestic sources and also external sources during 1991-92 to 2006-07.

\begin{tabular}{|c|c|c|c|c|c|c|c|c|}
\hline \multirow{2}{*}{ Year } & \multicolumn{3}{|c|}{ Production ('000MT) } & \multirow{2}{*}{$\begin{array}{l}\text { Total rice production/ } \\
\text { availability ('000MT) }\end{array}$} & \multirow{2}{*}{$\begin{array}{l}\text { Total requirement } \\
\text { ('000 MT) }\end{array}$} & \multirow{2}{*}{ Gap } & \multirow{2}{*}{$\begin{array}{l}\text { Food availability } \\
\text { gm/cap/day }\end{array}$} & \multirow{2}{*}{$\begin{array}{l}\text { External sources aid } \\
+ \text { import ('000MT) }\end{array}$} \\
\hline & Aus & Aman & Boro & & & & & \\
\hline 1991-92 & 2179 & 9269 & 6804 & 18252 & 18710 & -458 & 454 & - \\
\hline 1992-93 & 2075 & 9680 & 6586 & 18341 & 19040 & -699 & 445 & 1183 \\
\hline 1993-94 & 1850 & 9419 & 6772 & 18041 & 19370 & -1329 & 440 & 966 \\
\hline 1994-95 & 1791 & 8504 & 6538 & 16833 & 19700 & -2867 & 428 & 2568 \\
\hline 1995-96 & 1676 & 8790 & 7221 & 17687 & 20030 & -2343 & 439 & 2427 \\
\hline 1996-97 & 1871 & 9552 & 7460 & 18883 & 20360 & -1477 & 430 & 967 \\
\hline 1997-98 & 1875 & 8850 & 8137 & 18862 & 20690 & -1828 & 455 & 1951 \\
\hline 1998-99 & 1617 & 7736 & 10552 & 19905 & 21040 & -1135 & 522 & 5491 \\
\hline 1999-00 & 1734 & 10306 & 11027 & 23067 & 21380 & 1687 & 514 & 2104 \\
\hline 2000-01 & 1916 & 11249 & 11921 & 25086 & 21510 & 3575 & 545 & 1554 \\
\hline 2001-02 & 1808 & 10726 & 11766 & 24300 & 21790 & 2510 & 521 & 1798 \\
\hline 2002-03 & 1850 & 11115 & 12222 & 25187 & 22090 & 3097 & 564 & 3220 \\
\hline 2003-04 & 1832 & 11520 & 12838 & 26190 & 22380 & 3810 & 554 & 2788 \\
\hline 2004-05 & 1500 & 9819 & 13837 & 25156 & 22680 & 2476 & 539 & 3374 \\
\hline 2005-06 & 1745 & 10810 & 13975 & 26530 & 23010 & 3520 & 534 & 2459 \\
\hline 2006-07 & 1512 & 10841 & 14965 & 27318 & 23250 & 4068 & 540 & 1440 \\
\hline
\end{tabular}


The cropping intensity is determined as the ratio of total cropped area of multiple crops within a year to net cultivated area, which is expressed in terms of percentage. Farmers typically grow one or two crops per year and leave their lands fallow for rest of the time. The cropping intensity increased by 154 to 176 percent within the period of 1981-82 to 2006-07 (Table 1), while in some regions it was about 200 percent (Bogra and Comilla district). The rapid boost of cropping intensity was possible due to expansion of irrigated area and development of irrigation technologies in Bangladesh.

\section{Food Requirements and Availability}

It is observed that from 1991-92 towards 1998-99 there were deficit in rice production and the deficit ranged from 458 to 2867 thousand metric tons.

Later, the country reached to a marginally self-sufficient in rice production and it exceeded the country's total requirement of about 1600 to 4000 thousand metric tons. In reality the country with this small amount of surplus production is in a vulnerable situation as it is always threatened by frequent disasters like drought, flood, cyclone and sidr etc, which causes damage to the country's valued rice crops almost every year [1]. As a result, the government has to seek for foreign aid and import every year to make food reserve as buffer stock (Table 2). The amount of import and foreign aid varies according to extent of natural calamity and domestic production. The external sources of food was highest (5491 thousand MT) in 1998-99 as country was severely affected by flood. Boro rice usually, is less affected by natural disaster and consequently occupied largest share (55 percent in 2006-07) of total rice production. Moreover, 98 percent of boro rice is HYV and produced under irrigated condition.

\section{Trends of Rice Production in Bangladesh}

Within the crop sub-sector, food grains particularly the rice dominates in respect to both cropped area and production [13]. The following Figure 1 shows the trend of rice production in Bangladesh during 1980-81 to 2005-06. The production of aus rice was decreased while aman and boro rice was increased over the period of 1981-82 to 2005-06. Again, the fluctuation of aman rice as well as aus rice production was common due to the above named disasters and natural calamities. In 1988-89, 1998-99 and 2004-05 production year, aman rice production was drastically fall because of devastating flood all over the country (Figure 1). In such circumstances, people rely on boro rice production and they provide full efforts to overcome the crisis. Boro rice compensated the deficits because of its less reliant on nature and varietal improvement. Moreover, effective implementation of rehabilitation programs by the government and timely supply of inputs including irrigation equipments was also another reason of success. The $\mathrm{R}^{2}$ value was higher for boro rice production than aman rice production.

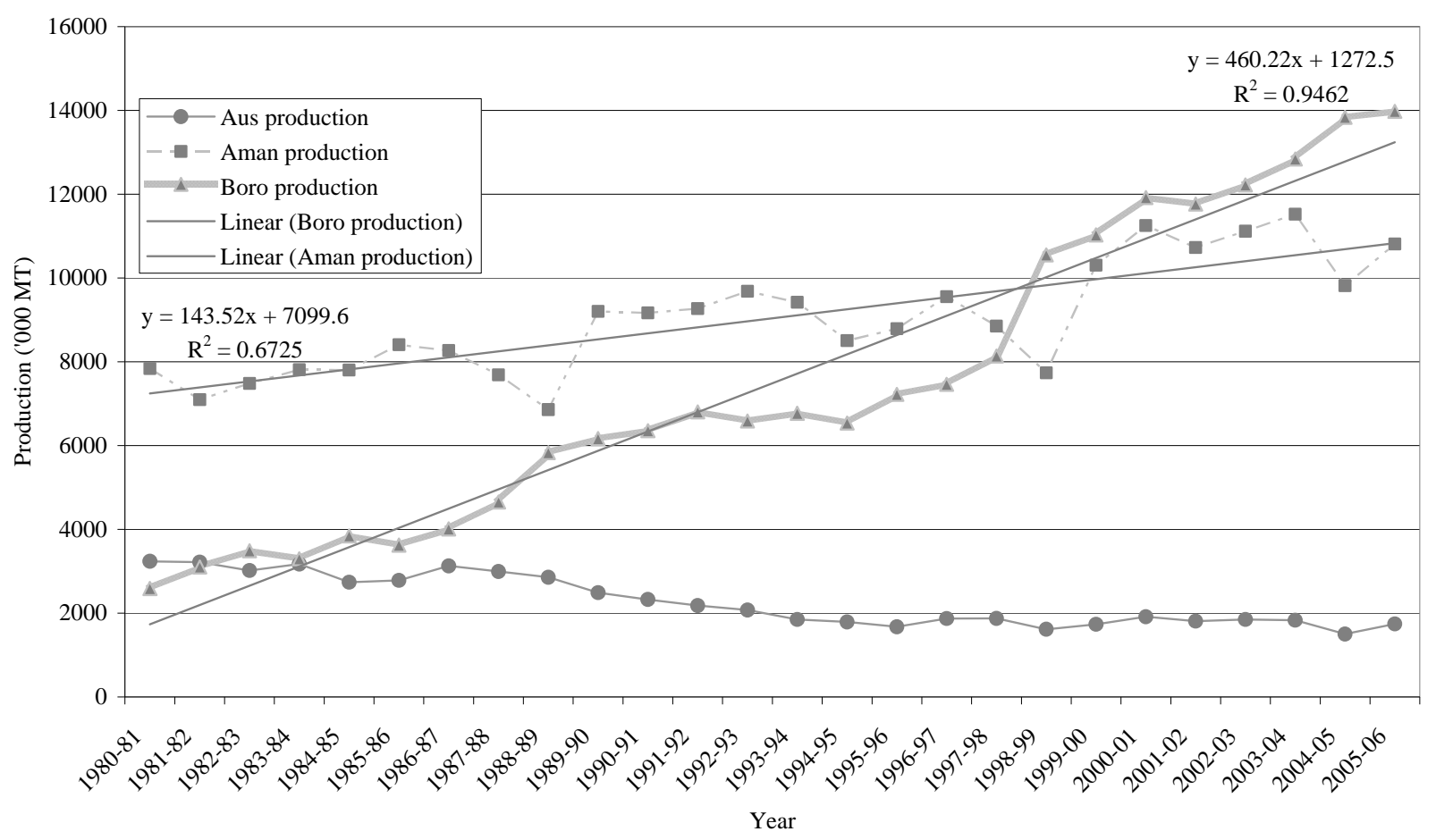

Figure 1. Trend of aus, aman and boro rice production in Bangladesh. 


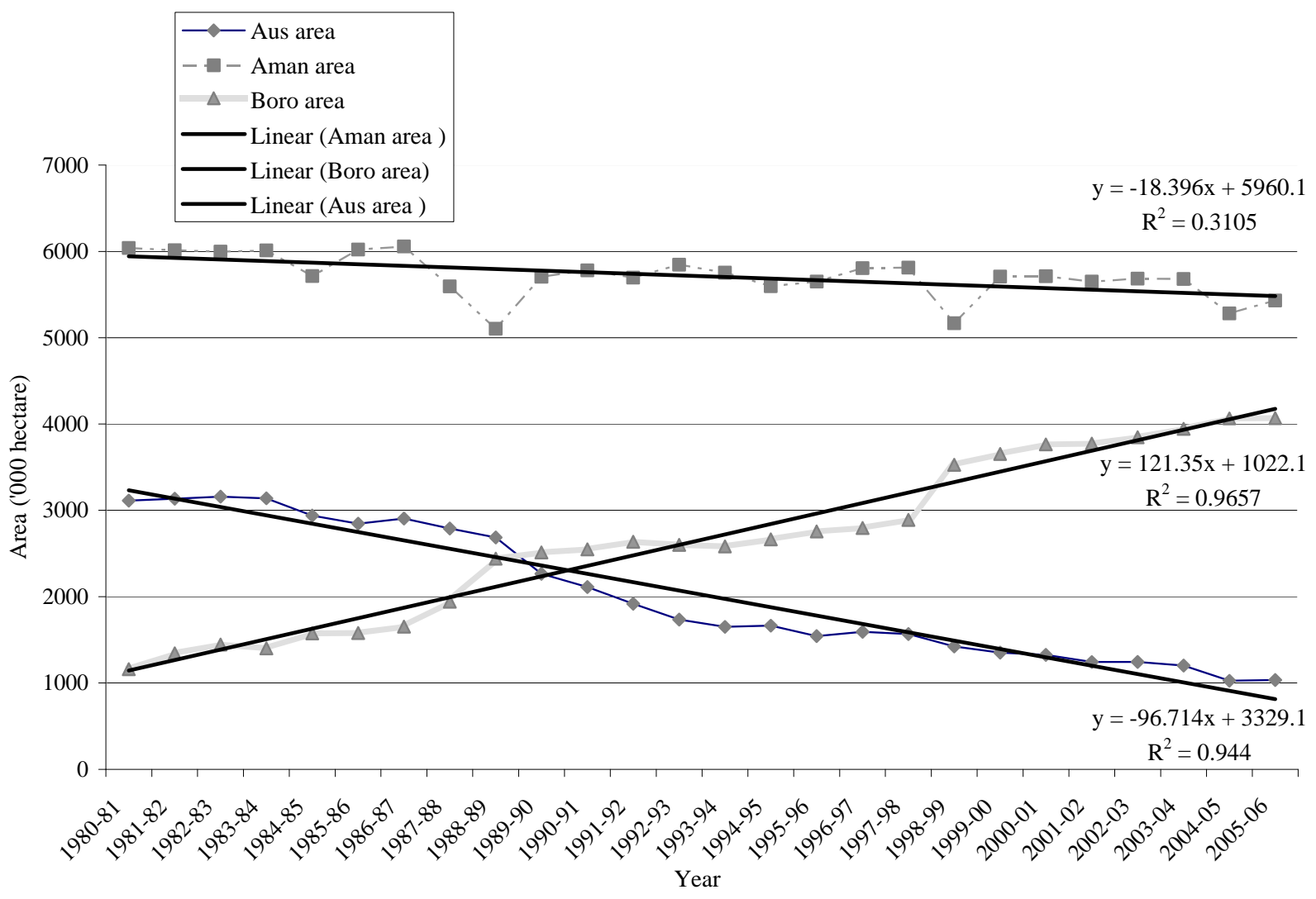

Figure 2. Trend of aus, aman and boro cultivated area in Bangladesh.

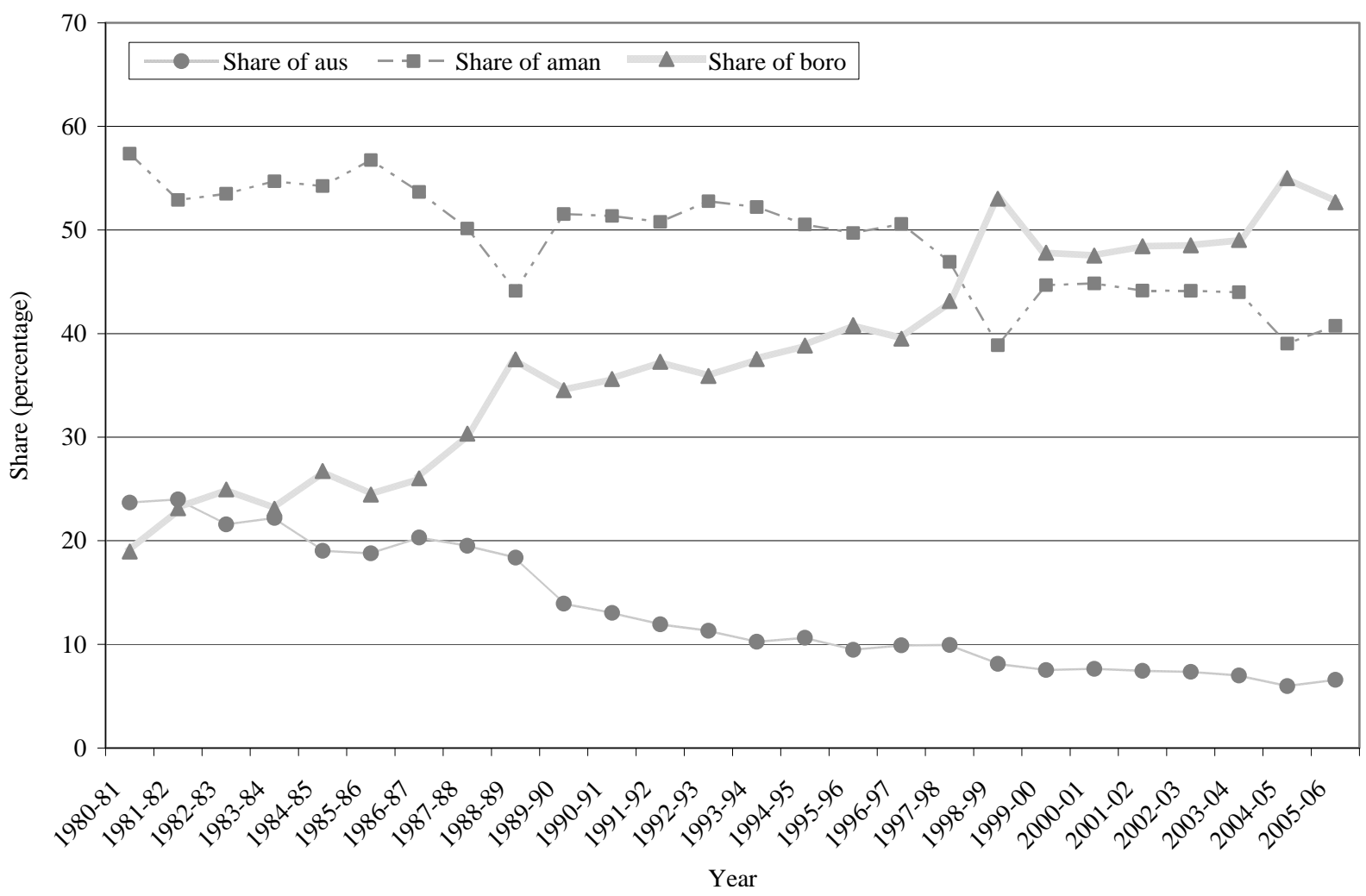

Figure 3. Percentage of aus, aman and boro production of total rice production in Bangladesh. 


\section{Trend of Rice Cultivated Area in Bangladesh}

At present, rice covers 75 percent of total cultivable land in Bangladesh [5]. Figure 2 depicts the trend of different rice cultivated area during $1980-81$ to 2005-06. It is interesting that most of aus rice cultivated areas were occupied by boro rice while aman cultivated area slightly declined over the time. It might be the reason of relatively less varietal improvement of aus and aman rice than boro rice and seasonal calamity. In the year of 1980-81 the boro cultivated area was 1161 thousand hectares and it was increased by 4068 thousand hectares after three decades of irrigation development while aus rice production area decreased by 3113 to 1035 thousand hectares within this period of time. On the other hand, aman cultivated area declined but still its occupied higher area than others. The fluctuation of aman cultivated area was also observed particularly in the natural disadvantaged years.

\section{Contribution of Boro Rice to Total Rice Production}

Boro rice is relatively free from weather hazard as it is grows in winter season. As a result, quick adoption of boro rice by the farmers' remarkably increased which made a substantial contribution to food grain production as well as agricultural development as a whole in Bangladesh [14]. The share of total rice production in different types of rice for the period of 1980-81 to 2005-06 is shown in Figure 3. At the initial stage of irrigation technology development, Boro rice contribution was lowest among different seasonal rice (aus and aman) but it is occupying the highest position since 1998-99 to date. In 1980-81 aman rice dominated and contributed to 57 percent of total rice production while aus and boro rice contribution was only 24 and 19 percent respectively. Figure 3 show that boro rice contribution to total rice production was in an increasing trend and increased by 55 percent in 2004-05 from 19 percent in 1980-81. Meanwhile aus rice contribution decreased at a greater length which could be due to traditional cultivation method, less varietal improvement and its replacement by boro rice.

\section{Per Hectare Yield of Different Seasonal Rice}

The average rice yield of Bangladesh is lower than in Asian countries like India, China [7]. Figure 4 shows per hectare yield of aus, aman and boro rice during 1980-81 to 2005-06. However, it was noted that all kind of rice yield was in an increasing trend and the gap between aus and aman rice yield was more or less similar. But the boro rice yield was about two and three times higher than aman and aus rice respectively. The major reason behind such differences observed was because boro rice

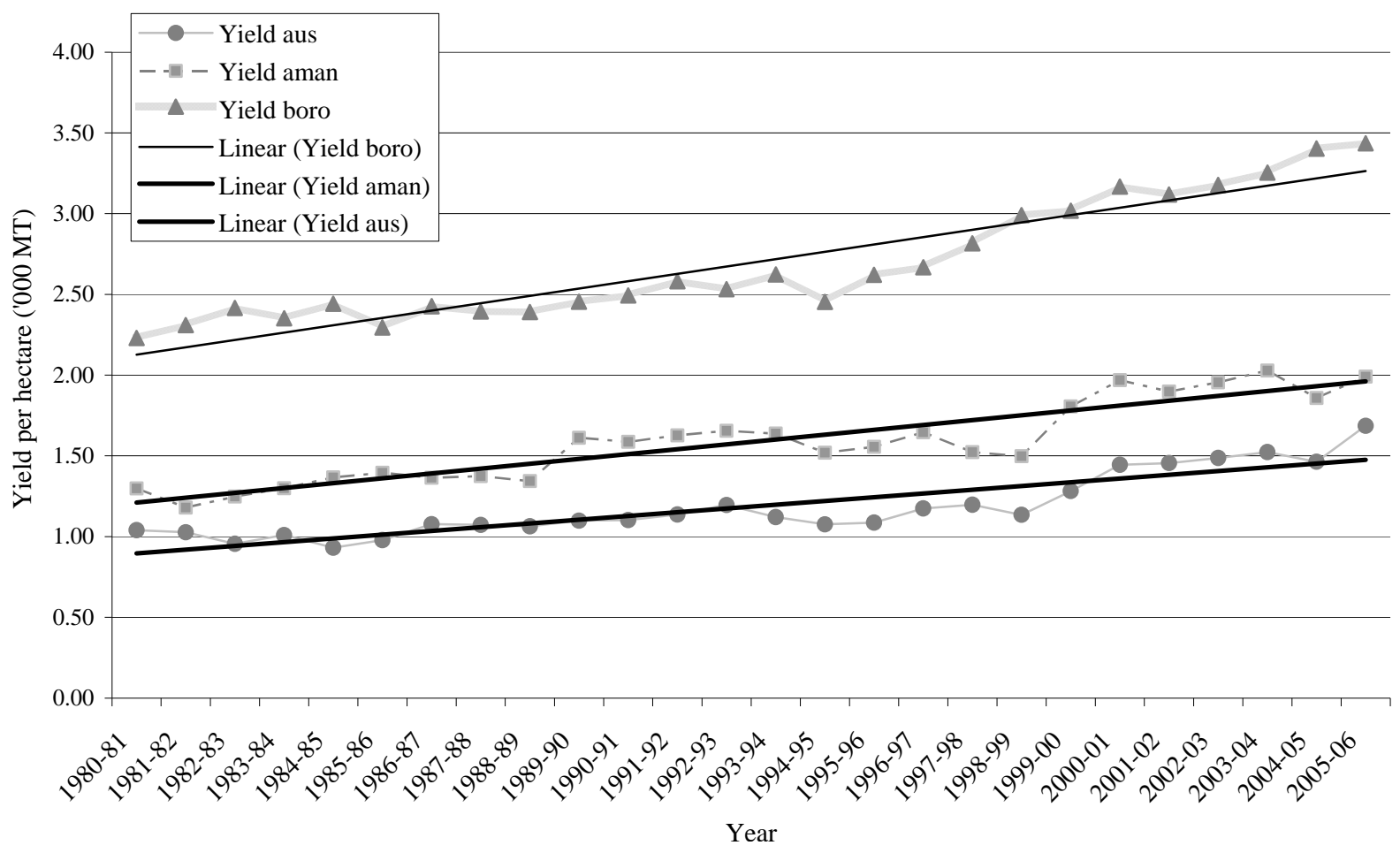

Figure 4. Per hectare yield of aus, aman and boro during 1980-81 to 2005-06 in Bangladesh. 


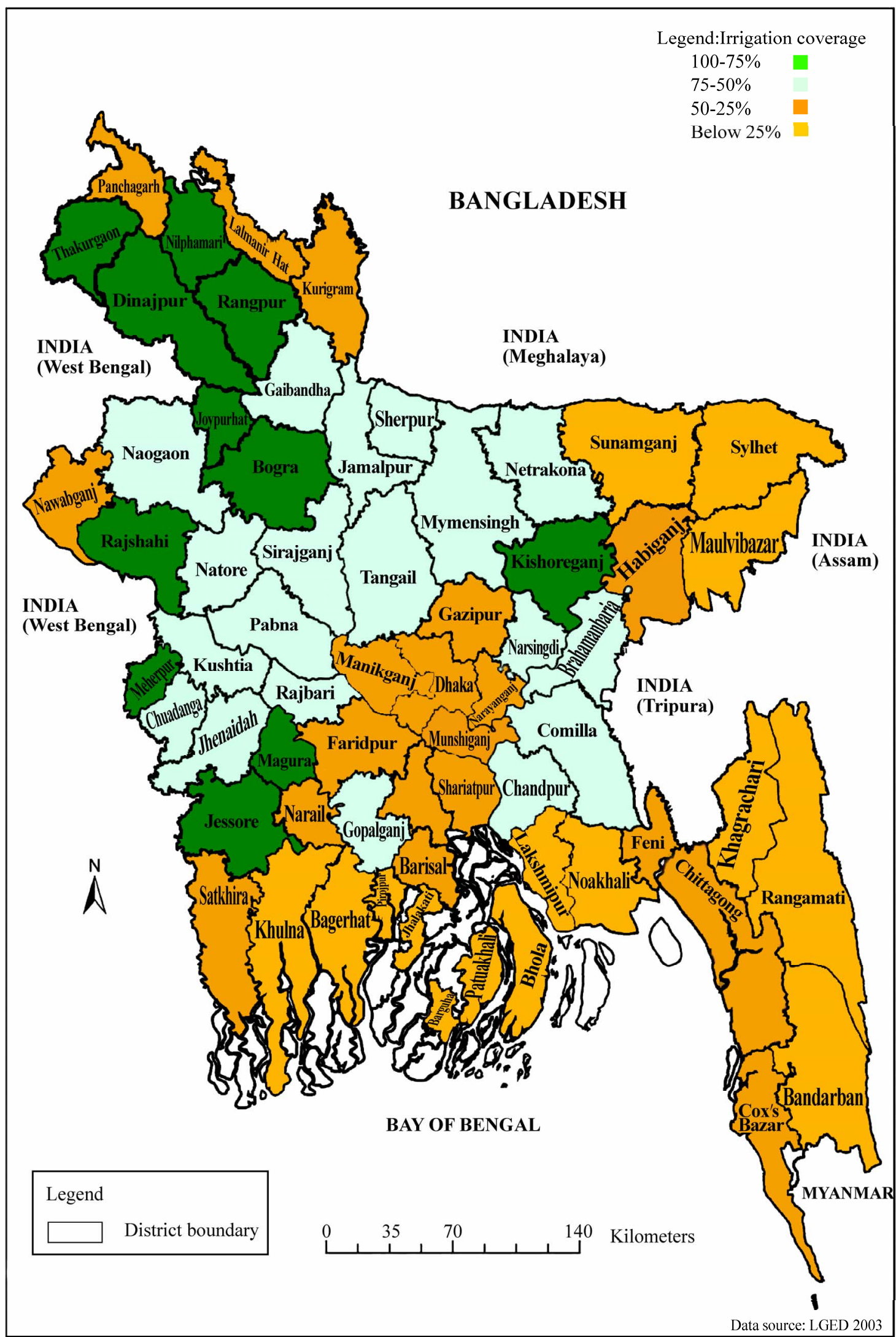

Map 1. Percentages of irrigation in different region of Bangladesh. 
varieties (97 percent) were High Yielding Variety (HYV) while it was less common for aus and aman rice. Figure 4 represent that though per hectare production increased till (2005-06), it did not exceed 2 MT/ha. for aus and aman rice yield whereas boro rice yield was about 2 MT/ha. in 1980-81 (the initial stage of groundwater irrigation) its yield increased by 65 percent (2.23 MT/ha. in 1980-81 and 3.44 MT/ha. in 2005-06) during last three decades.

\section{Irrigation Coverage in Different Region}

Irrigation coverage is not equally distributed all over the country because of different topography, availability of modern irrigation technology and socio-economic status of farmers. Map 1 shows the percentages of irrigation coverage in different region of Bangladesh in the production year of 2007-08. Four colours used to indicate the extent of irrigated area in different regions. It is observed that percentage of irrigated area was highest (green colour, 100-75 percent) which constituted 11 districts out of 64 districts and mostly situated in the north and north-western part of the country. There were also 19 districts moderately irrigated (75-50 percent mentioned as sky colour) composing upper middle and mid eastern part of the country. Another 19 districts were 50-25 percent under irrigated condition constituted in the middle and lower part of the country. Remaining 15 districts mostly situated in the hilly and coastal belt of the country had less irrigation coverage (below 25 percent). In recent time government has taken some initiative to expand irrigated area in the coastal belt by protecting coastal water resources [15].

\section{Relationship of Different Parameters}

\subsection{Area and Production}

Following Table 3 shows the relationship between cultivated area and production of different rice in Bangladesh.

It can be observed from table 3 that boro rice production was highly correlated $(\mathrm{r}=0.986)$ with cultivated area while aman rice production was negatively related. Aus rice production was also statistically significant at 1 percent level with cultivated area at a value of 0.703 which indicated strong correlation. The $\mathrm{R}^{2}$ value of linear model was .943, .012 and .972 for aus, aman and boro respectively which implied that independent variables (cultivated area) could explain 94, 1 and 97 percent of dependent variable (production) of aus, aman and boro rice respectively. More or less similar results also appeared in exponential growth model.

\subsection{Irrigated Area and Boro Rice Production}

Boro rice is grown on fully irrigated condition therefore, only relationship between boro rice production and irrigated area has been examined. The summary of the results are shown in Table 4 . The result shows that the increase of one hectare irrigated area added 3.22 MT rice considering boro rice production with irrigated area in Bangladesh. In addition $\mathrm{R}^{2}$ value explained about 96 percent of dependent variable (boro rice production) by the independent variable (total irrigated area). Moreover, Boro rice production was strongly correlated $(r=.986)$ with total irrigated area in Bangladesh.

Table 3. Relationship between cultivated area and production of rice during 1980-81 to 2005-06.

\begin{tabular}{|c|c|c|c|c|c|c|c|c|c|}
\hline \multirow{2}{*}{$\begin{array}{l}\text { Type } \\
\text { of rice }\end{array}$} & \multicolumn{4}{|c|}{ Linear model } & \multicolumn{4}{|c|}{ Exponential model } & \multirow{2}{*}{$\begin{array}{c}\text { Pearson } \\
\text { Correlation }(\mathrm{r})\end{array}$} \\
\hline & $\mathrm{R}^{2}$ & $\begin{array}{l}\text { Intercept } \\
\text { (a) }\end{array}$ & $\begin{array}{l}\text { Coefficient } \\
\text { (b) }\end{array}$ & $\mathrm{t}$ & $\mathrm{R}^{2}$ & $\begin{array}{l}\text { Intercept } \\
\text { (a) }\end{array}$ & $\begin{array}{l}\text { Coefficient } \\
\text { (b) }\end{array}$ & $\mathrm{t}$ & \\
\hline Aus & .943 & 752.71 & .7548 & $399.45 * *$ & .938 & 1149.48 & .0003 & $365.33^{* *}$ & $.703 * *$ \\
\hline Aman & .012 & 5897.70 & -.0206 & .596 & .008 & 5865.00 & -3.E-06 & .661 & $-.811 * *$ \\
\hline Boro & .972 & -2561 & 3.7764 & $818.16^{* *}$ & .993 & 1579 & .0005 & $3406 * *$ & $.986 * *$ \\
\hline
\end{tabular}

** indicates as 1 percent significant level (2 -tailed)

Table 4. Relationship between irrigated area and boro rice production during 1980-81 to 2005-06.

\begin{tabular}{cccccccccc}
\hline \multirow{2}{*}{$\begin{array}{c}\text { Type } \\
\text { of Rice }\end{array}$} & $\mathrm{R}^{2}$ & $\begin{array}{c}\text { Intercept } \\
\text { (a) }\end{array}$ & $\begin{array}{c}\text { Coefficient } \\
\text { (b) }\end{array}$ & $\mathrm{t}$ & $\mathrm{R}^{2}$ & $\begin{array}{c}\text { Intercept } \\
\text { (a) }\end{array}$ & $\begin{array}{c}\text { Coefficient } \\
\text { (b) }\end{array}$ & $\mathrm{t}$ & Pearson \\
correlation (r) \\
Boro rice & .957 & -3225.7 & 3.220 & $492.01^{* *}$ & .975 & 1490.70 & .0005 & $870^{* *}$ & $.978^{* *}$ \\
\hline
\end{tabular}

** indicates as 1 percent significant level (2 -tailed) 


\section{Conclusion and Suggestion for Policy Implication}

Irrigation is one of the key factors making the country self-sufficient in food grain production and contributes greatly towards agriculture GDP (Gross Domestic Production). Irrigation particularly ground water irrigation plays an important role for alleviating rural poverty in Bangladesh. It materialized that irrigation technologies are developing and small and medium farmers are involved more in the production process which enhanced their household food security in particular and national food security in general. From findings it appears that ground water irrigation has been given more emphasis from government as well as individual entrepreneur point of view though National Water Policy (NWPo) has highlighted the conjunctive use of surface and ground water [16]. Further more NWPo suggested to ensure the availability of water to all elements of society (poor, unprivileged), accelerating public and private water delivery system encompassing water right, water pricing, efficient water management considering economic efficiency, environmental degradation and climate change. Therefore, it should be given similar or more attention for the development of surface water irrigation in Bangladesh.

The average yield of rice is low especially for aus and aman rice as compared to Asian countries (India and China) therefore it is of urgent need to increase government investment in research for varietal improvement and on farm water management. Regarding varietal improvement, only 53 percent land was under HYV rice in case of aus cultivated area and it was 62 percent for aman rice in 2006-07. On the other hand HYV occupied 97 percent of boro rice cultivated area in the same year. Thus, there is a greater chance for varietal improvement to increase per unit production.

Increasing one hectare of irrigated area added 3.22 MT boro rice production therefore it is highly recommended for expansion of remaining land (28 percent) under irrigated condition for achieving country food requirements. However, there is a concern of arsenic contamination and declining water level due to ground water extraction over 20-30 years [17]. Boro rice production should be emphasized due to its less dependence on natural calamity, high varietal improvement (97 percent), and higher per unit production as compared to other seasonal rice (aus and, aman).

Existing institutions should be strengthened as well as capacity building for sustainable development and management of ground water and surface water irrigation due recent concerns about salinity, declining water level, ground water arsenic contamination, absence of irrigation pricing rules and regulations and power crisis etc. [18].Hence, formulation of "Groundwater and Surface water Act" is necessary for ensuring farmers benefit and long-run sustainability of natural resources. Irrigation has direct influence towards farmer's socio-economic status therefore; further study could investigate the implication of irrigation on poverty alleviation in rural Bangladesh.

\section{References}

[1] M. S. Alam, M. R. Islam, M. A. Jabber, M. S. Islam and M. A. Salam, "Institutional backup towards food security in Bangladesh," In Proceedings BKAS 13th National Conference and Seminar on Climate Changes: Food Security in Bangladesh, Vol. 13, Dhaka, Bangladesh PP, August 2008.

[2] R. K. Talukder, "Food security in Bangladesh: National and global perspectives,” In Proceedings BKAS 13th National Conference and Seminar on Climate Changes: Food Security in Bangladesh, Vol. 13, Dhaka, Bangladesh PP, August 2008.

[3] M. Z. Huda, "Regional development of irrigation technologies and its impact on food grain production in Bangladesh,” MS Thesis, Department of Agricultural Economics, BAU Mymensingh, Bangladesh, 2001.

[4] Bangladesh Economic Review (BER), Bangladesh Economic Survey, 2005, Finance Division, Ministry of Finance, Government of Bangladesh, Dhaka, Bangladesh, 2007.

[5] Bangladesh Bureau of Statistics, Statistical Year, Book of Bangladesh, Bangladesh Bureau of Statistics, Statistics Division, Ministry of planning, Government of People's Republic of Bangladesh, Dhaka, 2008. (http://www. bbs.gov. bd/ agriculture_wing/ annual_agri _ stat. pdf )

[6] T. Ernest, "Water profile of Bangladesh,” In: Encyclopedia of Earth. Eds. Cutler J. Cleveland (Washington, D. C.: Environmental Information Coalition, National Council for Science and the Environment), FAO, 2007.

[7] M. W. Rahman and R. Ahmed, "Shallow tube well irrigation business in Bangladesh,” Paper Presented at Summary and Synthesis Workshop at Kathmandu, Nepal, March 20-24, 2008.

[8] Bangladesh Bureau of Statistics, "Statistical year book of Bangladesh,” Bangladesh Bureau of Statistics, Statistics Division, Ministry of planning, Government of People's Republic of Bangladesh, Dhaka, 2007.

[9] Bangladesh Economic Review, Bangladesh Economic Survey, 2005, Finance Division, Ministry of Finance, Government of Bangladesh, Dhaka, Bangladesh, 2006.

[10] A. Zahid and S. R. U. Ahmed, "Groundwater resources development in Bangladesh: Contribution to irrigation for food security and constraints to sustainability,” Groundwater Governance in Asia Series-1, pp. 25-46, 2006.

[11] R. P. Jones, "Irrigation service market in Bangladesh: Private provision of local public goods and community regulation,” Paper Presented in Workshop on Managing Common Resources at the Department of Sociology, Lund University, Sweden, 2001. 
[12] M.A.S Mandal Ed "Dynamics of Irrigation Market in Bangladesh, Changing Rural Economy of Bangladesh. Bangladesh Economic Association, Dhaka, 2000.

[13] Fifth Five Year Plan "Mid- term review of the Fifth Five Year Plan 1997-2002”, Planning Commission, Ministry of Planning, Government of Bangladesh, Dhaka, Bangladesh, 2000.

[14] S. Islam and A.N M.R Karim Ed, "Increasing Rice Production in Bangladesh: Challenges and Strategies” International Rice research Institute, Los Banos, 1999

[15] M. K. Mondal, T.P Tuong, S.P Ritu, M.H.K Chowdhury, A. M Chasi, P.K Majumder, M.M Islam and S.K Adhikary “ Coastal water resource use for higher productivity; Participatory research for increasing cropping intersity in Bangladesh" Paper presented in the international conference on Environmental and livelihoods in the coastal zones; managing agriculture- aquaculture conflicks held in Bac Lieu, Vietnam, March 2005.

[16] NWPo. (1999). National Water Policy, Ministry of Water Resources, Dhaka, Bangladesh, 1999.

[17] Stephan K, R. Kipfer, Olaf A. C, Charles F. Harvey, M S. Brennwald, K. N. Ashfaque, A B M. Badruzzaman, S J. Hug, and Dieter M. (2006) Groundwater Dynamics and Arsenic Mobilization in Bangladesh Assessed Using Noble Gases and Tritium, Environmental Science and Technology,.(http://pubs.acs.org/doi/abs/10.1021/es0512 4w)

[18] M. A Sattar, and M. Moniruzzaman "Innovative Ricebased Farming Practices for Increasing Food Security in the Changing Coastal Environment of Bangladesh', in proceedings BKAS $13^{\text {th }}$ National conference and seminar on Climate Changes: Food Security in Bangladesh, Vol. 13, Dhaka, Bangladesh, August 2008. 